\title{
PENGARUH KUALITAS PELAYANAN DENGAN MENERAPKAN PROTOKOL KESEHATAN COVID - 19 TERHADAP MINAT SISWA/I SMP DAN SMA DI KECAMATAN BALEENDAH UNTUK MENGIKUTI BIMBINGAN BELAJAR (STUDI KASUS BIMBINGAN BELAJAR ENS)
}

\author{
${ }^{1}$ Riyan Hadithya \\ 2 Riski Taufik Hidayah \\ ${ }^{1}$ Universitas Informatika dan Bisnis Indonesia \\ Program Studi Manajemen, Fakultas Ekonomi, Universitas Informatika dan Bisnis Indonesia \\ riyanhadithya95@gmail.com \\ 2 Universitas Widyatama \\ Program Studi Manajemen, Fakultas Bisnis dan Manajemen, Universitas Widyatama \\ riski.taufik@widyatama.ac.id
}

\begin{abstract}
This study aims to analyze the impact of service quality by implementing the Covid-19 health protocol on purchase intention in EnS tutoring. EnS is a tutoring service that focuses on school students. The research was conducted because currently Indonesia is being hit by the Covid-19 pandemic, which requires students to learn from home online. However, there are many obstacles faced by students including the inadequacy of technology-based learning facilities, ranging from the gadgets used to the limited internet network. Also starting to get bored of students to study online and not all students understand the material when learning is done online. This study is devoted to counseling services based on the Covid-19 health protocol among middle and high school students in Baleendah District, Bandung Regency. Respondents of this study were 100 junior high school and high school students who were divided into 25 junior high school student respondents and 25 high school student respondents. The research instrument used was a questionnaire. From the research result, it shows that the influence of the service quality variable on students purchase intention is equal to 0.476 or $47.6 \%$, while the rest is influenced by other factors not examined. The results of the analysis of service quality on purchase intention show that service quality variable has a positive and significant effect on purchase intention.
\end{abstract}

Key words: service quality, health protocol, purchase intention

\begin{abstract}
ABSTRAK
Penelitian ini bertujuan untuk menganalisa dampak kualitas pelayanan dengan penerapan protokol kesehatan Covid - 19 terhadap minat beli bimbingan belajar EnS. EnS adalah jasa bimbingan belajar yang berfokus kepada siswa/I sekolah. Penelitian dilakukan karena saat ini Indonesia sedang dilanda pandemi Covid - 19 yang mengharuskan siswa/I untuk belajar dari rumah secara daring. Namun, banyak kendala yang dihadapi oleh siswa/I diantaranya kurang siapnya sarana belajar berbasis teknologi, mulai dari gadget yang digunakan sampai jaringan internet yang terbatas. Juga mulai jenuhnya siswa/I untuk belajar secara daring dan tidak semua siswa/I memahami materi apabila pembelajaran dilakukan secara daring. Pada penelitian ini dikhususkan pada layanan bimbingan berbasis protokol kesehatan Covid - 19 di kalangan siswa/I SMP dan SMA di Kecamatan Baleendah Kabupaten Bandung. Responden penelitian ini adalah 100 siswa/I SMP dan SMA yang dibagi menjadi 25 responden siswa/I SMP dan 25 responden siswa/I SMA.
\end{abstract}


Instrumen penelitian yang digunakan adalah kuesioner. Dari hasil penelitian menunjukkan pengaruh variabel kualitas pelayanan terhadap minat beli siswa/I sebesar 0,476 atau 47,6\%, sedang sisanya dipengaruhi oleh faktor lain yang tidak diteliti. Hasil analisis kualitas pelayanan terhadap minat beli menunjukkan bahwa, variabel kualitas pelayanan berpengaruh secara positif dan signifikan terhadap minat beli.

Kata kunci: kualitas pelayanan, protokol kesehatan, minat beli

\section{PENDAHULUAN}

\section{Latar Belakang}

Negara kita pada saat ini tengah menghadapi pandemi virus Covid - 19 yang berdampak pada banyak sektor, salah satunya pada sektor Pendidikan. Pemerintah menerapkan beberapa kebijakan seperti adaptasi kebiasaan baru atau new normal, PSBB (Pembatasan Sosial Berskala Besar) dan saat ini sedang berlangsung adalah PPKM (Penerapan Pembatasan Kegiatan Masyarakat). Dengan kebijakan yang dikeluarkan oleh pemerintah, tenaga pendidik dan peserta didik diminta untuk melakukan pembelajaran secara daring dari rumah sehingga tidak terjadi tatap muka di kelas seperti biasanya, tentunya tetap dituntut untuk adanya ketercapaian dan tujuan Pendidikan yang tetap berkualitas dan bermutu.

Permasalahan yang dihadapi adalah pembelajaran daring ini tidak lepas dari penggunaan alat elektronik seperti handphone, tablet atau laptop yang tidak semua siswa mempunyai alat elektronik tersebut dan mampu menggunakannya dengan baik. Juga harus ditunjang dengan koneksi internet yang baik seperti adanya fasilitas Wi-fi dan keterjangkauan sinyal provider di setiap penjuru daerah yang kekuatan sinyalnya berbeda. Penerapan PJJ saat ini menggunakan pembelajaran daring dengan beberapa platform aplikasi seperti Zoom, Google Meet, Google Classroom dan Edmodo. Adapun aplikasi lain yang banyak digunakan selain aplikasi - aplikasi sebelumnya adalah WhatsApp karena dinilai lebih mudah digunakan oleh banyak siswa maupun guru. (jurnal)

Dalam upaya meningkatkan beli, kualitas pelayanan juga berperan dalam mempengaruhi minat beli sebuah jasa. Pada penelitian Aptaguna dan Pitaloka (2016), hasil penelitian menunjukan bahwa variabel kualitas pelayanan berpengaruh secara signifikan terhadap minat beli jasa GO-JEK GO-Ride. Pada penelitian lain yang dilakukan oleh Ade (2020), hasil penelitian menunjukan bahwa kualitas pelayanan berpengaruh positif terhadap minat beli pelanggan. 
Kejenuhan belajar adalah kondisi emosional dan mental yang mengalami kelelahan yang sangat pada saat belajar, sehingga ia merasa lesuh dan sudah tidak dapat menampung materi atau informasi yang baru. Hal itu dapat disebabkan karena rentang waktu yang digunakan pada saat belajar relative cukup lama (Moh Agus Rohman, 2018). Pembelajaran secara daring pada saat ini mulai membuat para siswa mulai merasa jenuh. Siswa terbiasa berada di sekolah untuk berinteraksi dengan teman - temannya dan bertemu dengan gurunya. PJJ atau Pembelajaran Jarak Jauh membuat para siswa harus terus beradaptasi dengan kebiasaan baru dan mempengaruhi daya serap belajar mereka. Jika para siswa sudah mengalami rasa jenuh dalam pembelajaran daring, maka anak akan sulit untuk berkonsentrasi dalam proses pembelajaran. Beberapa orang tua siswa dan siswa menginginkan pembelajaran tatap muka bisa terlaksana kembali, namun dalam kondisi saat ini belum bisa terlaksana karena faktor keamanan siswa dan para guru serta tingkat penyebaran virus Covid - 19 ini masih tinggi. Model pembelajaran langsung adalah pembelajaran yang paling banyak digermari oleh siswa, terutama untuk mata pelajaran yang membutuhkan praktek dan eksak seperti Matematika, Kimia, Fisika dan Ekonomi. Alasannya adalah karena penjelasan materinya bisa diuraikan dengan jelas apabila dilakukan secara tatap muka.

Bimbingan belajar saat ini sangat terdampak sekali akibat dari adanya pandemi Covid 19, sehingga banyak bimbingan belajar yang sudah mempunyai nama yang besar atau pun yang masih skala kecil terpaksa harus mengurangi operasionalnya hingga harus tutup. Salah satu bimbingan belajar yang masih bertahan adalah Bimbel EnS, yang berada di Kecamatan Baleendah, Kabupaten Bandung, lokasinya berada di pusat pendidikan Kabupaten Bandung. Dampak dari pandemi Covid - 19 bisa terlihat dari turunnya jumlah siswa yang mengikuti bimbingan belajar di Bimbel EnS, seperti pada tabel berikut:

Tabel 1 Jumlah Siswa 3 Tahun Terakhir

\begin{tabular}{|c|c|}
\hline Tahun Pelajaran & Jumlah Siswa \\
\hline $2018-2019$ & 125 \\
\hline $2019-2020$ & 101 \\
\hline $2020-2021$ & 35 \\
\hline
\end{tabular}


Berdasarkan data di atas, dapat dilihat terjadi penurunan jumlah siswa dimulai pada tahun ajaran 2019 - 2020 yang bertepatan dengan awal kejadian pandemi Covid - 19 pada bulan Maret 2020 yang membuat beberapa siswa memutuskan untuk berhenti mengikuti bimbingan belajar dan puncaknya pada tahun ajaran 2020 - 2021 karena adanya ketakutan dari siswa maupun orang tua apabila siswa - siswa tersebut tertular oleh virus Covid - 19. Dengan melihat hal itu, Bimbel EnS melakukan penerapan protokol Kesehatan diantaranya:

1. Menyediakan fasilitas tempat cuci tangan dan menyediakan hand sanitizer di setiap ruangan.

2. Wajib mencuci tangan sebelum memasuki ruangan dan akan dilakukan pengecekan suhu menggunakan thermogun, apabila suhu di atas 37,5 derajat celcius maka tentor dan siswa dipersilahkan pulang untuk beristirahat.

3. Tentor dan siswa wajib menggunakan masker dan face shield selama proses pembelajaran berlangsung.

4. Pembatasan jumlah siswa dalam 1 kelas hanya 10 orang dan antar kursi diberikan jarak .

5. Durasi belajar dipersingkat menjadi 120 menit.

6. Pertemuan dilakukan $2 \mathrm{x}$ dalam seminggu.

7. Siswa diperbolehkan berkonsultasi secara daring dengan tentor mata pelajaran apabila ada hal yang ingin ditanyakan berkaitan dengan materi.

Penerapan protokol kesehatan tersebut dilakukan oleh Bimben EnS untuk memfasilitasi siswa - siswa yang memang membutuhkan bantuan dari bimbingan belajar dan dilakukan secara tatap muka, sekaligus untuk menghidupkan kembali atau menarik minat siswa atau orang tua siswa untuk bergeabung di bimbingan belajar EnS. Dengan adanya bantuan dari bimbingan belajar, diharapkan para siswa bisa terbantu, terfasilitasi dan mengurangi tingkat kejenuhan yang dihadapi selama PJJ (Pembelajaran Jarak Jauh).

Tujuan dilakukannya penelitian ini adalah untuk mengetahui pengaruh kualitas pelayanan dengan penerapan protokol Kesehatan Covid - 19 terhadap minat siswa/I SMP dan SMA di Kecamatan Baleendah untuk mengikuti bimbingan belajar EnS Baleendah. Manfaat yang diharapkan dari hasil penelitian ini adalah bisa menjadi panduan bagi bimbingan belajar untuk terus meningkatkan kualitas pelayanannya dengan menerapkan protokol kesehatan Covid - 19 sehingga siswa bisa belajar dengan nyaman dan berminat untuk bergabung mengikuti bimbingan 
belajar. Berdasarkan latar belakang di atas, kami tertarik untuk melakukan penelitian yang berjudul "Pengaruh Kualitas Pelayanan Dengan Menerapkan Protokol Kesehatan Covid - 19 Terhadap Minat Siswa/I SMP dan SMA di Kecamatan Baleendah Untuk Mengikuti Bimbingan Belajar (Studi Kasus Bimbingan Belajar EnS)"

\section{Kualitas Pelayanan}

Kualitas pelayanan terhadap suatu barang dan jasa akan sangat bersifat dinamis tergantung kepada ekspektasi dari manusia, terdapat lima dimensi yang dapat mempengaruhi kualitas pelayanan (Arie dalam Ade, 2020):

1. Tangible (bukti fisik), kualitas yang secara langsung dapat dirasakan masyarakat baik dari sisi tampilan maupun perlakuan yang dirasakan dalam pelayanan.

2. Reliability (kehandalan), yaitu pelayanan yang dirasakan oleh konsumen sesuai dengan janji yang sebelumnya disampaikan, yang merupakan suatu pelayanan minimal.

3. Responsiveness (daya tanggap), yaitu perilaku tanggap dalam melayani.

4. Assurance (jaminan), yaitu suatu jaminan akan kualitas dan keamanan.

5. Empathy (empati), yaitu sikap yang sangat memperhatikan pelanggan, peduli terhadap kepentingan pelanggan yang dilakukan secara individual.

Penerapan kualitas pelayanan ini diterapkan ke dalam panduan protokol kesehatan Covid - 19 yang di himbau oleh pemerintah saat ini yaitu penerapan gerakan 5M, penerapannya sebagai berikut:

1. Tangible, menyediakan fasilitas cuci tangan, handsanitizer di setiap ruangan dan menyediakan masker apabila ada siswa yang tidak membawa masker.

2. Reliability, tentor dan siswa wajib menggunakan masker dan face shield selama proses pembelajaran, diarahkan untuk mencuci tangan sebelum memasuki gedung dan pengecekan suhu badan.

3. Responsiveness, siswa diperkenankan berkonsultasi mengenai materi atau tugas dengan tentor melalui daring.

4. Assurance, siswa dipersilahkan langsung pulang setelah kegiatan belajar selesai, adanya pengaturan jarak kursi antar siswa minimal 1 meter, waktu pembelajaran maksimal 2 jam, jumlah siswa dibatasi untuk menghindari kerumunan. 
5. Emphaty, tentor atau siswa akan dipersilahkan pulang dan beristirahat apabila suhu tubuh diatas 37,5 derajat celcius,

\section{Minat Beli}

Schiffman dan Kanuk (2007) menyatakan bahwa minat merupakan salah satu aspek psikologis yang memiliki pengaruh cukup besar terhadap sikap serta perilaku. Kerin dalam Aries, Sunarti dan Mawardi (2018) menyatakan bahwa minat beli ialah kecenderungan seorang konsumen dalam membeli suatu merek, atau mengambil sebuah tindakan yang berhubungan dengan pembelian.

Schiffman dan Kanuk dalam Aries, Sunarti dan Mawardi (2018) menyatakan terdapat beberapa indicator untuk mengukur minat beli, yaitu :

1. Tertarik untuk mencari informasi mengenai produk.

2. Ingin mengetahui produk.

3. Tertarik untuk mencoba.

4. Mempertimbangkan untuk membeli.

5. Ingin memiliki produk.

\section{Kerangka Konseptual Penelitian}

\begin{tabular}{|c|c|}
\hline $\begin{array}{c}\text { Kualitas Pelayanan } \\
(\mathrm{X})\end{array}$ & $\begin{array}{c}\text { Minat Beli } \\
(\mathrm{Y})\end{array}$ \\
\cline { 2 - 3 }
\end{tabular}

\section{Hipotesis}

Berdasarkan kerangka pemikiran teoritis yang telah dikemukakan, maka hipotesis yang diajukan dalam penelitian ini adalah:

1. Kualitas pelayanan berpengaruh signifikan terhadap minat beli siswa. 


\section{METODE PENELITIAN}

\section{Jenis Penelitian}

Jenis penelitian yang dilakukan dalam penelitian ini adalah dengan menggunakan metode kuantitatif.

\section{Waktu dan Tempat Penelitian}

Penelitian ini dilakukan pada bulan Januari 2021 dan dilakukan di Kecamatan Baleendah, Kabupaten Bandung.

\section{Subjek Penelitian}

Populasi dari penelitian ini adalah Siswa/I SMP dan SMA yang ada di Kecamatan Baleendah, Kabupaten Bandung. Penentuan sampel dilakukan kepada beberapa siswa/I SMP dan SMA yang ada di Kecamatan Baleendah. Menurut Ferdinand (2006), dalam menentukan jumlah sampel yang representative adalah tergantung pada jumlah indicator dikali 5 sampai 10. Jumlah sampel minimum untuk penelitian ini adalah:

Sampel minimum = Jumlah indikator $\mathrm{x} 5$

$$
=10 \times 5=50 \text { responden }
$$

Maka sampel yang akan digunakan adalah 50 responden, yang terbagi menjadi 25 responden siswa SMP dan 25 responden siswa SMA.

\section{Prosedur Penelitian}

1. Observasi (Pengamatan): Pengumpulan data dengan melihat langsung, mendengar, dan menganati objek yang akan diteliti dan dipergunakan untuk menyesuaikan data yang diperoleh.

2. Wawancara: Pengumpulan data dengan tanya jawab secara langsung dengan pemilik bimbel untuk memperoleh data yang akurat.

3. Kuesioner: Berisi sejumlah pertanyaan secara tertulis yang ada kaitannya dengan masalah yang sedang diteliti yang diajukan kepada konsumen. 


\section{Data, Instrumen, dan Teknik Pengumpulan Data}

Peneliti melakukan wawancara langsung kepada pemilik bimbingan belajar EnS untuk mengetahui masalah yang dihadapi dan mendapatkan data mengenai jumlah siswa dalam 3 tahun terakhir. Lalu untuk mendapatkan hasil kuesioner untuk penelitian ini, peneliti menyebarkan kuesioner menggunakan link Google Form kepada responden agar tidak terjadi kontak langsung dengan responden dalam bentuk fisik.

\section{Teknik Analisis Data}

\section{Analisis Regresi Linier Sederhana}

Menurut Sugiyono (2014) analisis regresi linier sederhana adalah "Regresi sederhana didasarkan pada hubungan fungsional atau kausal satu variabel independen dengan satu variabel dependen". Analisis regresi linier sederhana digunakan untuk menguji sifat hubungan sebab-akibat antara variabel independen $(\mathrm{X})$ terhadap variabel dependen $(\mathrm{Y})$.

\section{Uji t}

Digunakan untuk menguji berarti atau tidaknya hubungan variabel-variabel independent Kualitas Pelayanan (X) dengan variabel dependen Minat Beli (Y). Untuk membuat kesimpulannya sebagai berikut :

(1) Bila (P Value) < 0,05 maka H0 ditolak dan H1 diterima. Artinya variable independent secara parsial mempengaruhi variabel dependent.

(2) Bila (P Value) > 0,05 maka H0 diterima dan ditolak. Artinya variable independent secara parsial tidak mempengaruhi variabel dependent.

\section{Uji Koefisien Determinasi}

Koefisien determinasi $\left(\mathrm{R}^{2}\right)$ dilakukan untuk melihat adanya hubungan yang sempurna atau tidak, yang ditunjukkan pada apakah perubahan variabel bebas (kualitas pelayanan) akan diikuti oleh variabel terikat (minat beli) pada proporsi yang sama. Pengujian ini dengan melihat nilai $\mathrm{R}$ Square (R2). Nilai koefisien determinasi adalah antara 0 sampai dengan 1. (Ghozali, 2005).

\section{HASIL PENELITIAN DAN PEMBAHASAN}

\section{Hasil Penelitian}

\section{Analisis Regresi Linear Sederhana}


Tabel 2 Analisis Regresi Linear Sederhana

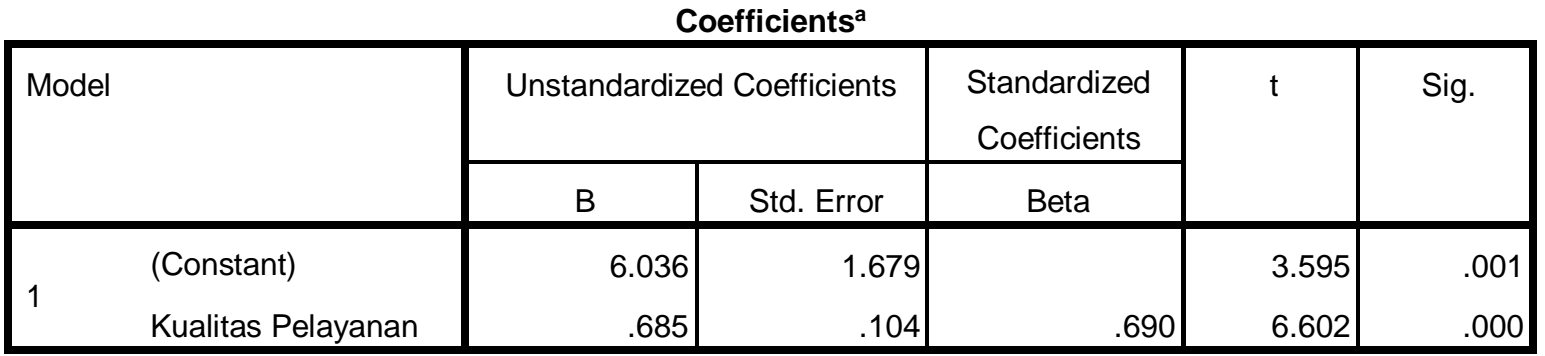

a. Dependent Variable: Minat Beli

\section{Uji t}

Tabel 3 Uji t

\begin{tabular}{|c|c|c|c|c|c|c|}
\hline \multicolumn{7}{|c|}{ Coefficients $^{a}$} \\
\hline \multirow{2}{*}{\multicolumn{2}{|c|}{ Model }} & \multicolumn{2}{|c|}{ Unstandardized Coefficients } & Standardized & \multirow[t]{2}{*}{$\mathrm{t}$} & \multirow[t]{2}{*}{ Sig. } \\
\hline & & $\mathrm{B}$ & Std. Error & Beta & & \\
\hline \multirow{2}{*}{1} & (Constant) & 6.036 & 1.679 & & 3.595 & .001 \\
\hline & Kualitas Pelayanan & .685 & .104 & .690 & 6.602 & .000 \\
\hline
\end{tabular}

a. Dependent Variable: Minat Beli

\section{Koefisien Determinasi}

Tabel 4 Hasil Koefisien Determinasi

Model Summary

\begin{tabular}{|l|r|r|r|r|}
\hline Model & $\mathrm{R}$ & R Square & Adjusted R Square & $\begin{array}{c}\text { Std. Error of the } \\
\text { Estimate }\end{array}$ \\
\hline 1 & $.690^{\mathrm{a}}$ & .476 & .465 & 2.010 \\
\hline
\end{tabular}

a. Predictors: (Constant), Kualitas Pelayanan

\section{Pembahasan}

Dalam pengolahan analisis regresi linear sederhana, didapatkan persamaan regresi linear sederhana dapat dirumuskan $Y=6,036+0,685 X$. Karena nilai koefisiensi regresi bernilai positif 
(+), maka dengan demikian dapat dikatakan bahwa Kualitas Pelayanan (X) berpengaruh positif terhadap Minat Beli (Y). Hal ini bisa disebabkan oleh siswa/I mempunyai minat untuk mengikuti bimbingan belajar dengan penerapan protokol kesehatan Covid - 19 karena siswa/I sudah mulai jenuh dalam proses Pembelajaran Jarak Jauh (PJJ). Selain itu didukung juga dengan nilai signifikansi variabel Kualitas Pelayanan sebesar 0,000 lebih kecil dari < 0,05, sehingga dapat disimpulkan $\mathrm{H} 0$ ditolak dan $\mathrm{H} 1$ diterima. Yang berarti bahwa terdapat pengaruh antara Kualitas Pelayanan (X) terhadap Minat Beli (Y). Dalam penghitungan koefisien determinasi, dapat diketahui bahwa R Square memiliki nilai sebesar 0,476. Artinya, variabel Kualitas Pelayanan memberikan pengaruh terhadap Minat Beli sebesar 47,6\% dan sisanya 52,4\% dipengaruhi oleh faktor lain yang tidak diteliti.

\section{KESIMPULAN DAN IMPLIKASI}

\section{Kesimpulan}

Berdasarkan hasil penelitian dapat disimpulkan bahwa variabel kualitas pelayanan berpengaruh secara positif dan signifikan terhadap minat beli. Kualitas pelayanan yang diberikan Bimbel EnS dalam bentuk penerapan protokol kesehatan Covid - 19 untuk proses belajar mengajar menjadi kekuatan yang dimiliki oleh Ens untuk mendorong minat siswa/I untuk menggunakan jasa bimbingan belajar. Oleh karena itu, diharapkan EnS dapat terus mempertahankan dan meningkatkan kualitas pelayanannya kepada siswa/I atau orang tua siswa. terutama dalam penerapan proses belajar dengan protokol kesehatan Covid -19 .

\section{Implikasi}

Hasil penelitian memiliki implikasi yang dapat digunakan sebagai pertimbangan oleh EnS dalam menentukan kebijakannya. Adapun skala prioritas kebijakan berdasarkan hasil penelitian adalah sebagai berikut:

1. Menjaga dan meningkatkan kualitas pelayanan khususnya dalam penerapan protokol kesehatan Covid - 19, agar bisa menjadi daya tarik minat sisw/I untuk bergabung dengan EnS.

2. Membuat suasana lebih nyaman dan aman pada saat siswa/I sedang menjalankan proses belajar. 
Adapun implikasi yang bisa dipertimbangkan oleh peneliti selanjutnya sebagai berikut:

1. Diharapkan penelitian ini bisa menjadi panduan bagi peneliti selanjutnya yang akan meneliti penerapan protokol kesehatan Covid - 19 di lingkungan pendidikan, khususnya untuk bimbingan belajar.

2. Mengingat penelitian mengenai topik ini masih jarang ditemui, peneliti mengharapkan ada penyempurnaan penelitian yang lebih baik lagi untuk selanjutnya.

\section{DAFTAR PUSTAKA}

Augusty, F. (2006). Metode Penelitian Manajemen: Pedoman Penelitian untuk Skripsi, Tesis dan Disertasi Ilmu Manajemen. Semarang: Universitas Diponegoro.

Ghozali, I. (2005). Aplikasi Analisis Multivariate dengan SPSS. Semarang: Badan Penerbit Universitas Diponegoro.

Schiffman, Kanuk. (2007). Perilaku Konsumen. Edisi Kedua. Jakarta: PT. Indeks.

Sugiyono. (2014). Metode Penelitian Pendidikan Pendekatan Kuantitatif, Kualitatif dan R\&D. Bandung: Alfabeta.

Abidah, A., Hidaayatullaah, H.N., Simamora, R.M., Fehabutar, D., Mutakinati, L. (2020). The Impact of COVID-19 to Indonesian Education and Its Relation to the Philosophy of "Merdeka Belajar". Studies in Philosophy of Science and Education, 1(1), 38 - 49. https://doi.org/10.46627/sipose.v1i1.9

Ali, W. (2020). Online and Remote Learning in Higher Education Institutes: A Necessity in Light of COVID-19 Pandemic. Canadian Center of Science and Education, 10(3), 16 - 25. https://doi.org/10.5539/hes.v10n3p16

Aptaguna, A., Pitaloka, E. (2016). Pengaruh Kualitas Layanan dan Harga Terhadap Minat Beli Jasa Go -Jek. Widyakala Journal, Journal of Pembangunan Jaya University, 3, 49 - 56. https://www.upj.ac.id/userfiles/files/WIDYAKALA\%20VOL\%203\%20pp\%204956\%20(Aptaguna_Oka).pdf

Aries, M., Sunarti, Mawardi., M. (2018). Pengaruh Word of Mouth Terhadap Minat Beli Serta Dampaknya Pada Keputusan Pembelian (Survei Pada Make Up Artist yang Membeli dan Menggunakan Produk KRYOLAN di Kabupaten Bojonegoro). Jurnal Administrasi Bisnis, 60(3), $\quad 36 \quad-\quad 44$. http://administrasibisnis.studentjournal.ub.ac.id/index.php/jab/article/view/2530

Chertoff, J.D., Zarzour, J.G., Morgan, D.E., Lewis, P.J.L., Canon, C.L., Harvey, J.A. (2020). The Early Influence and Effects of the Coronavirus Disease 2019 (COVID-19) Pandemic on Resident Education and Adaptations. Journal of the American College of Radiology, 17(10), 1322 - 1328. https://doi.org/10.1016/j.jacr.2020.07.022 
Chinmi, M., Marta, R.F., Haryono, C.G., Fernando, J., Goswami, J.K. Exploring Online News as Comparative Study Between Vendatu at India and Ruang Guru from Indonesia in COVID19 Pandemic. Journal of Content, Community \& Communication, 11(6), 167 - 176. https://doi.org/10.31620/JCCC.06.20/13

Dewa, C., Safitri, L. (2020). Analisa Pengaruh Kualitas Pelayanan dan Kepuasan Pelanggan Terhadap Loyalitas Pelanggan OVO pada masa Physical Distancing. Asset: Jurnal $\begin{array}{llllll}\text { Manajemen dan } & \text { Bisnis, } & 3(1), & 24 & - & 32 .\end{array}$ http://journal.umpo.ac.id/index.php/ASSET/article/view/2652/1475

Dwivedi, Y.K., Hughes, D.L., Coombs, C., Constantiou, I., Duan, Y., Edwards, J.S., et.al. (2020). Impact of COVID-19 Pandemic on Information Management Research and Practice: Transforming Education, Work and Life. International Journal of Information Management, 55, 102211. https://doi.org/10.1016/j.ijinfomgt.2020.102211

Fitri, B., Widyastutik, O., Arfan, I. (2020). Penerapan Protokol Kesehatan Era New Normal dan Risiko Covid - 19 Pada Mahasiswa. Riset Informasi Kesehatan, 9(2), 143 - 153. http://stikes-hi.ac.id/jurnal/index.php/rik/article/view/460/145

Gottlieb, U.R., Brown, M.R., Drennan, J. (2011). The Influence of Service Quality and Trade Show Effectiveness On Post-Show Purchase Intention. European Journal of Marketing, 45(11/12), 1642 - 1659. https://doi.org/10.1108/03090561111167324

Hidayat, D., Anisti, Purwadhi, Wibawa., D. (2020). Crisis Management and Communication Experience in Education during the COVID-19 Pandemic in Indonesia. Malaysian Journal of Communication, 36(3), 67 - 82. https://doi.org/10.17576/JKMJC-2020-3603-05

Irawan, D., Triana, N., Suwarni, L., Selviana. (2020). Edukasi Protokol Kesehatan dan Strategi Pemasaran Online Melalui Program Kemitraan Masyarakat Di Era Pandemi Covid - 19. Jurnal Masyarakat Mandiri (JMM), 4(4), 655 - 662. http://journal.ummat.ac.id/index.php/jmm/article/view/2636/pdf

Maghfiroh, A., Arifin, Z., Sunarti. (2020). Pengaruh Citra Merek Terhadap Minat Beli dan Keputusan Pembelian (Survei pada Mahasiswa Prodi Administrasi Bisnis Tahun Angkatan 2013/2014 Fakultas Ilmu Administrasi Universitas Brawijaya Malang Pembeli Indosat Ooredoo). Jurnal Administrasi Bisnis, 40(1), 132 - 140. http://administrasibisnis.studentjournal.ub.ac.id/index.php/jab/article/view/1592

Nugroho, I., Yulianto, D. (2020). Penerapan Disiplin Protokol Kesehatan di Era Kenormalan Baru Pada Dunia PAUD. Jurnal Al - Hikmah, 8(1), 150 - 156. http://jurnal.staiba.ac.id/index.php/Al-Hikmah/article/view/166

Paiz, N.A.M., Ali, M.H., Abdullah, A.R., Mansor, Z.D. (2020). The Effects of Service Quality on Satisfaction and Purchase Intention in Mobile Commerce. Canadian Center of Science and Education, 15(4), 36 - 42. https://doi.org/10.5539/ijbm.v15n4p36

Permana. A. (2020). Pengaruh Kualitas Website, Kualitas Pelayanan dan Kepercayaan Pelanggan Terhadap Minat Beli Pelanggan di Situs Belanja Online Bukalapak. Journal of Economic and Business, 25(2), 94 - 110. https://doi.org/10.33592/jeb.v25i2.422 
Purwanto, A., Asbari, M., Fahlevi, M., Mufid, A., Agistiawati, E., Cahyono, Y., et al. (2020). Impact of Work From Home (WFH) on Indonesian Teachers Performance During the Covid-19 Pandemic: An Exploratory Study. International Journal of Advanced Science

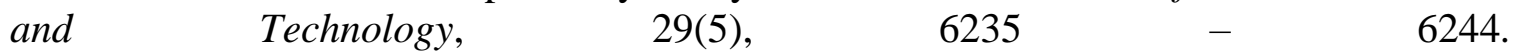
http://sersc.org/journals/index.php/IJAST/article/view/15627

Rinawati, D., Darisman, E. (2020). Survei Tingkat Kejenuhan Siswa SMK Belajar di Rumah Pada Mata Pelajaran Produk Kreatif dan Kewirausahaan Selama Masa Pandemi Covid - 19. Journal of Science and Education (JSE), 1(1), $32-40$. https://jse.rezkimedia.org/index.php/jse/article/view/11/5

Setiawan, B., Iasha, V. (2020). Covid-19 Pandemic: The Influence of Full-Online Learning for Elementary School in Rural Areas. Jurnal Pendidikan Sekolah Dasar, 6(2), 114 - 123. http://dx.doi.org/10.30870/jpsd.v6i2.8400.g5942

Syah, D., Utari, D., Adinugraha, T., (2020). Edukasi Penerapan Protokol Kesehatan Penyelenggaraan Kegiatan Baca Tulis Alquran Pada Masa Pandemi Covid 19 Di TPQ Masjid Awalulmu'minin Gamping. Jurnal Pengabdian Masyarakat Karya Husada $\begin{array}{lllll}(J P M K H), & 28 & - & 33 .\end{array}$ http://jurnal.poltekkeskhjogja.ac.id/index.php/jpmkh/article/view/408/252

Wu, P.C.S., Yeh, G.Y.Y., Hsiao, C.R. (2011). The Effect of Store Image and Service Quality on Brand Image and Purchase Intention for Private Label Brands. Australasian Marketing Journal (AMJ), 19(1), 30 - 39. https://doi.org/10.1016/j.ausmj.2010.11.001

Arif,

A.

$(2020$,

November

$15)$. https://www.ayosemarang.com/read/2020/11/15/67086/bimbingan-belajar-dan-mengajijadi-solusi-efektif-di-masa-pandemi

Nafisah, F. (2020, November 17). https://kumparan.com/ida-nafisah/bimbingan-belajar-di-masapandemi-covid-19-1ubKa4SR7Ko

Zein Fikri. Peran Bimbingan Belajar di Era Pandemi Covid - 19. Retrieved February 2, 2021 from https://www.neutron.co.id/info/peran-bimbingan-belajar-di-era-pandemi-covid-19

Rohman, M.A. (2018). Kejenuhan Belajar Pada Siswa di Sekolah Dasar Full Day School. Universitas Islam Negeri Sunan Ampel, Surabaya. 